Images in...

\title{
Disseminated leiomyomatosis peritonei
}

\author{
Tom Wiggins, ${ }^{1}$ Benjamin Michael Stubbs, ${ }^{2}$ Darren Boone, ${ }^{3}$ Alec Engledow ${ }^{1}$
}

1Department of Colorectal Surgery, University College Hospital, London, UK;

2Department of Surgery, University College Hospital, London, UK;

${ }^{3}$ Department of Radiology, University College Hospital, London, UK

Correspondence to Tom Wiggins, thomas.wiggins@hotmail.co.uk

\section{DESCRIPTION}

This 44-year-old female had multiple incidental intraperitoneal lesions identified during laparoscopy. Histological analysis showed the lesions were benign. Subsequent CT imaging demonstrated diffuse enhancing peritoneal lesions (arrowed) consistent with a diagnosis of disseminated leiomyomatosis peritonei (figure 1).

Disseminated leiomyomatosis peritonei is a rare benign condition causing multiple smooth muscle, myofibroblastic and fibroblastic nodules in the intraperitoneal cavity. ${ }^{1}$ Although the exact aetiology is unknown, it is thought to be caused by smooth muscle metaplasia of the subperitoneal multipotential mesenchymal cells. ${ }^{2}$ Due to the diffuse nature of the disease, surgical resection is not potentially curative but can be used to treat symptomatic lesions or if patients develop intestinal obstruction. However, reduction in lesion size has been described following chemotherapy in one case. ${ }^{3}$

Competing interests None.

Patient consent Obtained.

\section{REFERENCES}

1. Paul PG, Naik S. Disseminated leiomyomatosis peritonei. Incidental finding in laparoscopy: a case report. Surg Laparosc Endosc Percutan Tech 2010;20:e123-4

2. Kara ahin KE, Gezginç K, Ulubay M, et al. Disseminated peritoneal leiomyomatosis. Taiwan J Obstet Gynecol 2008;47:123-5.

3. Lin YC, Wei LH, Shun CT, et al. Disseminated peritoneal leiomyomatosis responds to systemic chemotherapy. Oncology 2009;76:55-8.

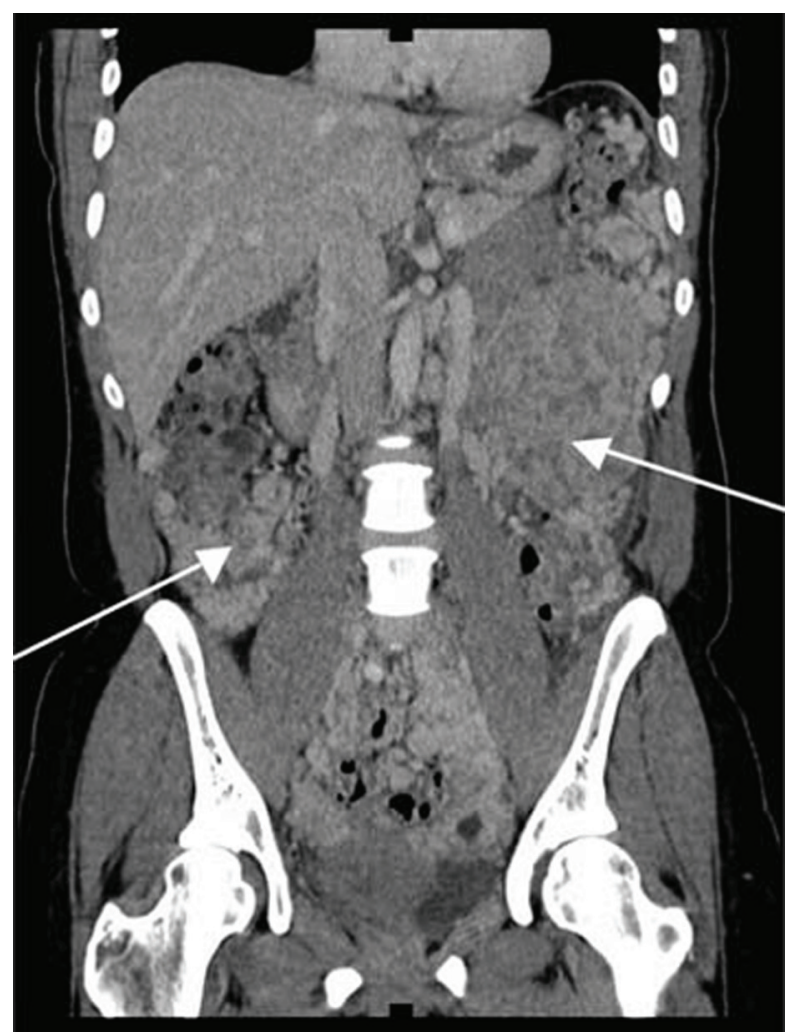

Figure 1 Coronal CT image showing multiple enhancing peritoneal lesions (arrowed).

This pdf has been created automatically from the final edited text and images.

Copyright 2011 BMJ Publishing Group. All rights reserved. For permission to reuse any of this content visit http://group.bmj.com/group/rights-licensing/permissions.

BMJ Case Report Fellows may re-use this article for personal use and teaching without any further permission.

Please cite this article as follows (you will need to access the article online to obtain the date of publication).

Wiggins T, Stubbs BM, Boone D, Engledow A. Disseminated leiomyomatosis peritonei. BMJ Case Reports 2011;10.1136/bcr.04.2011.4145, date of publication

Become a Fellow of BMJ Case Reports today and you can:

- Submit as many cases as you like

- Enjoy fast sympathetic peer review and rapid publication of accepted articles

- Access all the published articles

- Re-use any of the published material for personal use and teaching without further permission

For information on Institutional Fellowships contact consortiasales@bmjgroup.com

Visit casereports.bmj.com for more articles like this and to become a Fellow 